ISSN 2078-6441. Вісник Львівського університету. Серія географічна. 2013. Випуск 42. С. 121-127. Visnyk of the Lviv University. Series Geography. 2013. Issue 42. P. 121-127.

551.4

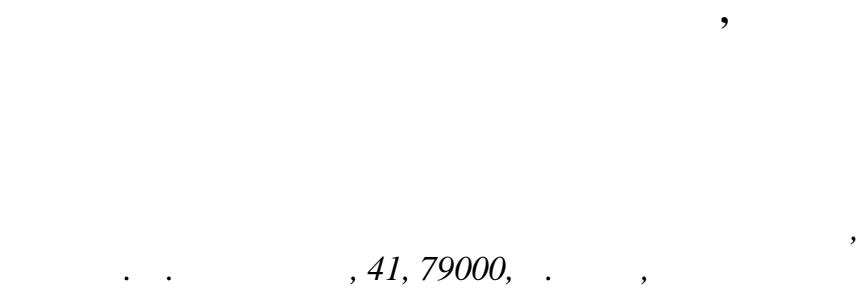

пис но геоморфологічні умови розт шув ння, морфометричні п р метри т чинники формув ння комплексу пісковикових скель у с. ерківн в східній ч стині ескидів. ро н лізов но попередні дослідження скель у цьому р йоні. икон но вимірюв ння т побудов но розуді гр му н пряму простяг ння тріщин різного генезису в тілі пісковиків. оротко опис но біорізном ніття н скелях, особливості т причини лок ліз ції різних видів рослин н них. формульов но рекоменд ції, поклик ні сприяти популяриз ції скель у ерківні, інформув нню про їхні геоморфологічні т історико-геогр фічні особливості, цінність і унік льність серед туристів т н уковців. кож рекомендов но дод ткові з ходи щодо збереження цих об'єктів.

лючові слов : морфометрія скель, форми скель, тріщини, формув ння скель.

оли йдеться про скелі ескидів, з звич й приг дують н йпопулярніші з них: “ келі овбуш " у с. убнище т скелі в с. рич. ст ннім ч сом до скельних утворень цього р йону підвищен ув г н уковців, зокрем геологів, геоморфологів т туризмозн вців. еред об'єктів, які входять до переліку цік вих, н с мперед є зг д ні вище, нині ж цей список поволі поповнюється. потреб поділу скель цього р йону н комплекси з уст леними н зв ми, дет льного т рівноцінного геоморфологічного опису кожного з них.

укові дослідження скель ескидів розпоч лося в 30-х рок х ХІХ ст. х проводили укр їнські т польські етногр фи, кр єзн вці, рхеологи, геологи т геоморфологи.

XIX-н поч тку ХX ст. скелями з цік вилися укр їнські вчені . гилевич,

олов цький, . рушевський $[4,14,18]$ т польські . іркор, . еметрикевич $[14,16]$, які описув ли здебільшого з г льні риси стрімч ків, форму, простяг ння т положення у рельєфі. 1894 р. офіційними укр їнськими польовими дослідженнями н території ескидів з йм лося укове тов риство ім. евченк н чолі 3 . рушевським.

еологічну будову і скл д порід скельних виходів ескидів н прикінці ст. вивч ли . уль і . ітце, . існевський, . блонський i . ейгнер. ст точно вік ямненських, вигодських т сп ських м сивних пісковиків, які утворюють стрімч ки н цій території, визн чили у 40-50-х рок х XX ст. [6].

прикінці ст. викон но н укові обстеження скель як осередків культури ст род вніх н родів кр їни [2]. рг нізов но першу конференцію, присвячену с ме цим об’єкт м [15], т кож викон но перший облік скель як геологічних п м'яток природи [10]. поч тку ст. велику ув гу приділяли скельним утворенням як тр кційним об'єкт м у г лузі туризму т рекре ції [11], дет льно досліджув ли породи рицьких скель з описом їхніх фізичних вл стивостей і петрогр фічного скл ду $[5,8]$.

(C) озуля ., 2013 
ескид х відомо 12 скельних комплексів, н йгустіше вони розт шов ні в меж х рівської скиби: рицький (скелі в с. рич), мельницький (в околицях с. мельниця) [7], ежибрідський (скелі біля гір ожерниця т околовець) [1], ишівницький (у с. ишівниця), рух нівсько- убнищ нський (в урочищі лесков те т н г. околов ). ступним досліджув ним комплексом скель $є$ ерков'янський, виявлений н кр йньому сході ескидів. і стрімч ки включені в л ндш фтний з к зник “ пове” з площею 6 г із з зн ченням н явності скель т джерел н території [13], проте їх нем є у списку геологічних чи геоморфологічних п м’яток природи. ет льніш інформ ція про них є лише в інтернеті [17]. вд нням є визн чити морфометричні пок зники скель, х р ктер їхніх обрисів, розчленов ність тріщин ми різного генезису т особливості формув ння в цей ч с.

ля визн чення морфометричних пок зників, лок ліз ції т висоти розт шув ння скель н д рівнем моря, т кож відносної висоти стрімч ків використ но GPS-н віг тор Garmin GPS 60, дод тково - мірну стрічку, комп с. кож комп сом вимірюв ли н прями простяг ння тріщин т п діння пл стів пісковику. ні вимірюв ння тріщин опр цьовув ли в прогр мі StereoNett.

3 хідній окр їні с. ерківн (ст р н зв - а́рківн ) олинського р-ну в но-

p нківської обл. у буковому лісі виявлено скелі, що м ють н зву “ пових” [17]. ей комплекс розт шов ний у межиріччі уж нки т іï притоки - потоку ерков'янський, н його пр вому березі, н північно-з хідному відрозі вершини омн тик $(897,7$ м). ериторія лежить у східній ч стині колівських ескидів у укельському геоморфологічному підр йоні. гідно з морфоструктурним і тектонічним р йонув нням рп т, це лобод - олехівськ морфоструктур четвертого порядку, як є ч стиною рівської скиби [9].

ідслонення пісковиків з вдовжки 850 м простяг ється зі сходу н 3 хід н північному схилі хребт з вершиною 758 м, н висоті від 600 до 727 м н д рівнем моря. хил, н якому розт шов ні скелі, - увігнутий, крутість його у верхній ч стині сяг є $40^{\circ}$.

г льн ширин виходів ямненського пісковику тут ст новить 100 м, м ксим льн ширин окремих монолітних скель 3 поперечною віссю відслонення - 18 м. исот стрімч ків зі збільшенням відносної висоти їхнього розт шув ння зрост $\epsilon$ i сяг $€$ м ксим льно 21 м.

сновний л нцюжок скель м є вигляд огорожі (див. рис. 1 ), прислоненої південним боком до гребеня хребт . ей л нцюг можн розділити н дві скельні групи: східну (з м ксим льними висот ми) т з хідну, розт шов ні н відст ні 50 м одн від одної. іж цими груп ми, обидві з яких з хов ні в лісі, яскр во виділяється н г лявині окрем скеля у формі гостроверхої плити 3,8 м з ввишки т 8 м з вдовжки.

ижче по схилу вздовж усієї огорожі х отично розкид ні численні брили-ул мки ді метром до 12 м, відірв ні колись від основи по тріщин х н ш рув ння, т кож тр пляються відділені від основного м сиву вертик льними тріщин ми й зсунені н відст нь до 10 м від нього скелі у вигляді веж і шпиць.

келі вздовж і впоперек розчленов ні різними тріщин ми. ріщини, які розділяють пригребеневу смугу пісковику н окремі скельні вежі з м йже прямовисними стінк ми т плоскими вершин ми, м ють к рп тський н прям - 305-310 (див. рис. 2). ріщини н ш рув ння, як і з г лом пл сти породи, помітні лише у привершинній ч стині скель (4, 3 і 1 м униз від брівок), їхні площини ляг ють м йже п р лельно до схилів (п діння пл стів - 15-23 у північному н прямі). решті площі ш ри порід пр ктично не помітні, с мі стрімч ки вигляд ють однорідними з скл дом. 


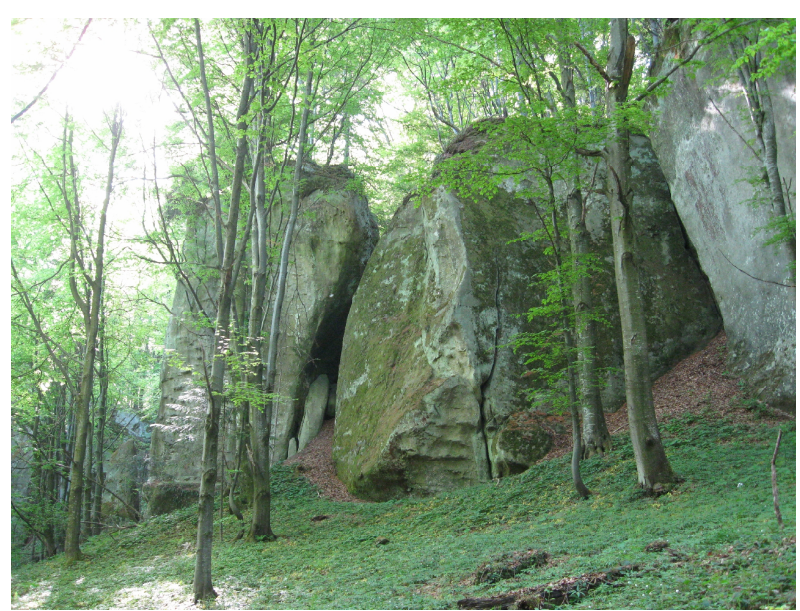

ис. 1. ежі як елементи скельної огорожі ерков'янського комплексу:

келі скл дені з пісковиків п леогенового віку, сформов них приблизно 56 млн років тому [6]. ідтвердженням їхньої н лежності до ямненської світи п леоцену є те що н північ від скель у підніжжі схилу виявлено мергелі, н гребені хребт вище скель зн йдено брили т ул мки кременю. гідно з д ними щодо геологічної будови цього р йону, ямненськ світ перекрит відкл д ми м нявської світи нижнього еоцену (піщ но-глинистий фліш 3 п чк ми кременів), нижче 3 ляг ють породи, у тому числі мергелі, стрийської світи верхньої крейди [9].

озвиток скель відбув ється головно з вдяки розвитку тріщин, т кож звітрюв нню т поступовому руйнув нню стінок стрімч ків.

иходи скельних порід розчленов ні н окремі стрімч ки тріщин ми тектонічного походження. они н денній поверхні виявляють лише верхню ч стину простяг ння, проте вглиб сяг ють н сотні метрів (до 275 м, згідно зі стр тигр фічною колонкою 1966 р.). і тріщини розвив ються вн слідок новітніх тектонічних рухів, спрямов них н підняття рп тської гірської системи. поверхні тектонічні тріщини з зн ють процесів звітрюв ння, які спричиняють формув ння стінок тріщин, винесення н повнюв ч і зумовлюють їхнє видиме розширення. озкриття тріщин змінюється від 2,5 до 5,0 м. хні стінки є м йже вертик льними, половин 3 них - н вісні. рост ння відст ні між стінк ми тріщин т кути їх п діння, близькі до $90^{\circ}$, сприяють більшому потр плянню н них сонячного тепл і світл, особливий х р ктер впливу вітру, дощу т снігу.

ронт льні стінки скель, зимути більшості яких збіг ються з н прямом із тектонічними тріщин ми $\left(220,310^{\circ}\right)$, ще більше підд ються впливу тмосферних, т кож біогенних, чинників.

ріщини н ш рув ння січуть скелі, формуючи сл бкон хилені, м йже горизонт льні площини. е перев жно з криті тріщини бо у вигляді прожилків. них кумулюється волог, як під дією добових колив нь темпер тур т інсоляції спричиняе руйнув ння ч стинок породи і розширення цих тріщин. о тріщин х н ш рув ння н 
поверхні скель утворюються к рнизи т ніші невеликого розміру. них з тримується н сіння рослин, яке, пророст ючи, поглиблює ці тріщини.

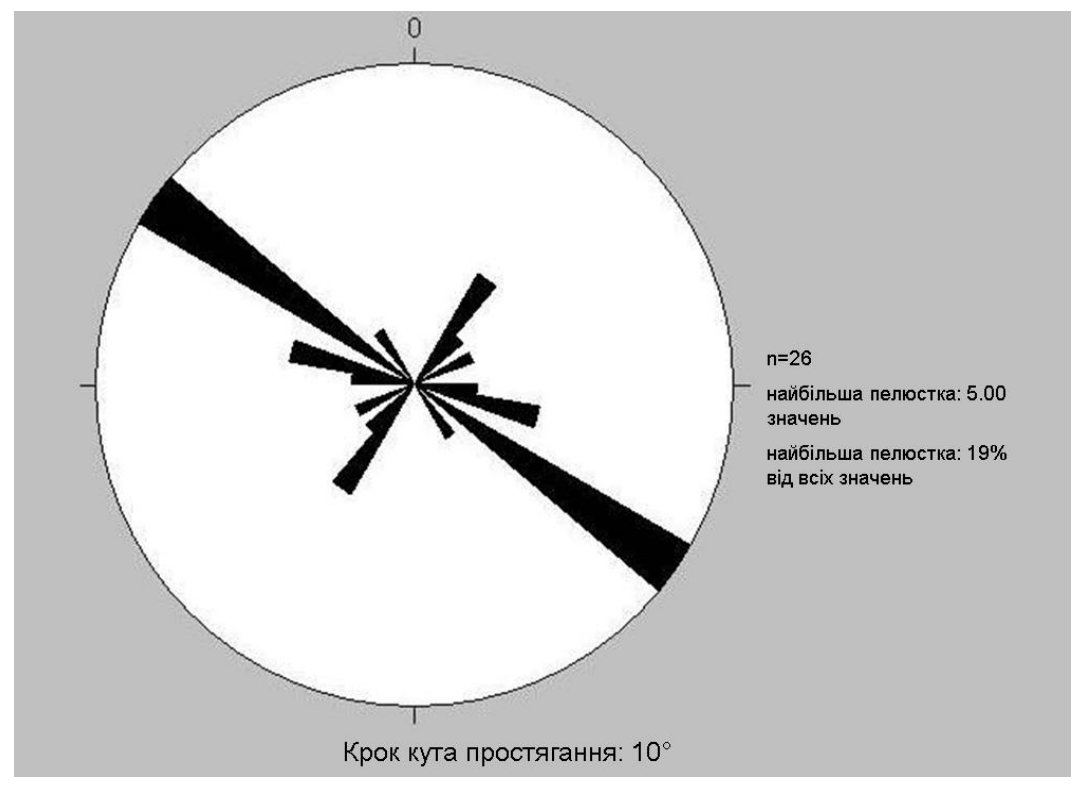

ис. 2. оз -ді гр м простяг ння тріщин різного генезису н “" пових скелях” (викон н в прогр мі StereoNett).

еликий вплив н формув ння скель м є експозиція схилів, н яких вони розт шов ні. келі у ерківні розміщені н схилі північної експозиції і прислонені до нього південним боком, їхні фронт льні стінки спрямов ні перев жно н північний з хід т північний схід. ільшість із них розт шов н н з ліснених ділянк х. они м ло н грів ються сонячними променями вдень і, відповідно, менше охолоджуються вночі, що зумовлює сл бкий розвиток фізичних процесів.

оверхня стрімч ків морфологічно неоднорідн . дні ділянки гл дкі й вирівняні, інші всіяні ніш ми невеликого розміру (ді метром до 0,2 м) т дугоподібними скол ми.

цих ніш х н копичується волог, як під ч с добових колив нь темпер тур ктивізує фізичне звітрюв ння н поверхні скель. омірки звітрюв ння у всьому ерков'янському комплексі тр пляються лише н двох скелях. н шу думку, їхня появ з лежить більше від хімічного скл ду породи, оскільки вони поширені н стінк х різних експозицій т н різній висоті скель. еоморфологічні з кономірності їхнього виникнення відшук ти в жко.

кож скелі вкриті мохово-лиш йниковою рослинністю. й ктивнішим видимим гентом звітрюв ння н них є лиш йники, які ростуть м йже н всій поверхні, тоді як мохи - перев жно у привершинній ч стині й біля підніжжя, т кож у ніш х т н всіх виступ х, де з тримується волог . устоті мохів сприяє пологість схилів і їхня з тіненість. они ростуть зрідк бо їх вз г лі нем н прямовисних т м ксим льно освітлених ділянк х, де вод вип ровується і нем є сприятливих умов для росту вологолюбних мохів. стінк х, які періодично освітлюються, моховий т лиш йниковий покрив 
різном нітніший, ніж н тих, які постійно перебув ють у тіні. ей покрив сприяє мех нічному т хімічному звітрюв нню, розпушув нню поверхні й зд тності утримув ти н д лі коріння вищих рослин. прикл д, н сонячних ділянк х скель пророст ють кущикові рослини (чорниця), як корінням поглиблює утворені $\mathrm{p}$ ніше тріщини т з глибини.

“ пові скелі” м ло змінені людиною і не відомі широкому з г лу туристів. ут нем $є \mathrm{x}$ р ктерних для популярніших скель ескидів вишкряб них н писів імен т н селених пунктів. підніжжі скель, н 3 хід від н йвищих з них, куст рним способом видобув ють пісок (очевидно, цим з йм ється місцеве н селення), проте ями, утворені вн слідок відбору піску, ді метром до 3 м і глибиною до 1 м н р зі н скелі ніяк не вплив ють.

ід ч с ругої світової війни скелі ст ли своєрідною твердинею для вояків сотні ея, які боролися тут у 1945 р. проти р дянських військ, про що свідчить т бличк н мет левому хресті, вст новленому н пісковиковому кург ні біля підніжжя н йвищої скелі. впроти могили обл штов но л вку, нижче по схилу - стіл з двом л в ми.

стінці цього стрімч к н прикінці 1980-х років (з перек 3 ми місцевих людей) виріз ли хрест з ввишки 4,5 м, поряд злів - тризуб, які добре збереглися (див. рис. 1б).

лизько двох років тому ці скелі поч ли освоюв ти скелел зи. 2012 р. тут відбувся всеукр їнський фестив ль скелел зів [12], проте слідів їхньої діяльності (н прикл д, г ків для кріплення скелел зного спорядження) поки не виявлено.

келі у с. ерківн є цік вими т зручними для туристів, у тому числі з вдяки н явності криниці з джерельною водою поблизу, освітлених г лявин непод лік, т кож тр кційному вигляду с мих стрімч ків.

тже, н околиці с. ерківн виявлено комплекс скель, який пропонуємо н зв ти ерков'янським. ін простяг ється із з ходу н схід н 850 м смугою скель т їхніх ул мків 100 м 3 вширшки. йвищі стрімч ки сяг ють тут 21 м. келі скл дені з пісковиків ямненської світи п леоцену. кельні породи експонуються у формі огорожі, розділеної тектонічними тріщин ми перев жно к рп тського н пряму н окремі стінки, вежі т шпиці. кремі брили у підніжжі скель відокремлені від них по тріщин х н Ш рув ння. ормув ння скель відбув ється з вдяки клім тичним т біогенним чинник м, т кож визн чене геологічними т тектонічними особливостями їхньої будови.

келі комплексу “ ерков'янський” не відомі в широких н укових кол х і н р зі не н дто популярні серед туристів. ожн спереч тися про те, чи в рто популяризув ти природні об’єкти, уболів ючи з їхнє ліпше збереження з вдяки невідомості.

оскільки скелі вже включені в межі л ндш фтного 3 к зник , то необхідно допомогти 3 цік вленим відвідув ч м дізн в тися більше про об'єкт. р зі тут ми не виявили ніяких вк зівників, які 6 скерув ли турист до скель бо повідомляли про природоохоронний ст тус території. оцільно прокл сти м ршрут, що передб ч в би огляд скель, вст новити дороговк зи т повідомлення про перебув ння у з повідній зоні, т кож т блиці з історико-геогр фічною, геоморфологічною т морфогенетичною інформ цією про ці об'єкти. кі з ходи свідчитимуть про унік льність т цінність ерков'янських стрімч ків, сприятимуть дб йливому ст вленню відвідув чів до скель т території, н якій вони розт шов ні. 
1. $и$ р $к$ еоморфологічні особливості ежибродського комплексу скель у ерхньодністерських ескид х / . йр к, . озуля // роблеми геоморфології і п леогеогр фії кр їнських рп т і прилеглих територій : м тері ли четвертого міжн родного семін ру ( орохт , 6-9 вересня 2012 р.). - ьвів :

ім. . p нК , 2012. - . 125-132.

2. ндрівський . . в рожі лики: н риси / . . ндрівський. - ьвів : огос, 1992. $-104 \mathrm{c}$.

3. огд нов . ітологічний т структурний спекти ямненської світи (про екзотичні утворення рп т) / . огд нов , . енер лов // існик ьвівського ун-ту. ер. геол. -2002 . - ип. 16. - . 109-105.

4. гилевич. ерди - в ричі / . гилевич // одорожі в кр їнські рп ти : збірник. - ьвів, 1993. - . 102-113.

5. олошин . нженерно-геоморфологічн х р ктеристик рицьких скель / . олошин // роблеми геоморфології і п леогеогр фії кр їнських рп т і прилеглих територій : м тері ли четвертого міжн родного семін ру ( орохт , 6-9 вересня 2012 р.). - ьвів : $\quad$ ім. . р нк , 2012. - . 172-180.

6. ялов . . леогеновый флиш северного склон рп т / . . ялов. - иев : , 1961. - $136 \mathrm{c.}$

7. врилів . еоморфологічні особливості п м'ятки природи “ омплекс м льовничих скель з лісон с дженнями н горі околовець"/ . врилів // укові з писки iм. . н тюк . ерія: геогр фія. пец. випуск: ст ле природокористув ння: підходи, проблеми, перспектив . - ернопіль : “ йп”, 2010. - № 1, вип. 27. . 386-390.

8. вришків . етрогр фія п леоценових відкл дів “екзотичних скель” кибової зони кр їнських рп т / . вришків // н-т геол. і геохім. горюч. коп лин кр їни. - ьвів, 2008. - . 67-69.

9. елогическ як рт . ист -34- . . . : 1966.

10. еологические п мятники кр ины: пр вочник, путеводитель / . . оротенко, . . ириц , . . невский [и др.] : 2-е изд. - иев : ук. думк, 1987. $.84-92$.

11. інько . кр їнсько-польський геотуристичний шлях “ ео- рп ти” / . інько, . к кун, . учинськ [т ін.] // існик ьвів. ун-ту. ер. міжн р. відносини. 2012. - ип. 25, .2. - .269-273.

12. $р$ вчук. . еоморфологія кибових рп т / росл в офронович $\mathrm{p}$ вчук. ьвів : ид в. центр ім. в н р нк , 2005.-232 c.-( ерія “ ельєф кр їни”).

13. риродні п м'ятки олинщини: нформ ційн довідк / олинськ центр льн р йонн бібліотек . - олин , 2009. - . 9.

14. ідуш . кельно-печерні природно- нтропогенні комплекси в л ндш фт х кр їнських рп т / . ідуш // Przemiany krajobrazu kulturowego Karpat: wybrane aspekty [Transformation of the cultural landscape of the Carpathians: selected aspects] // Prace Komisji Krajobrazu Kulturowego PTG. - Sosnowiec, 2004. - N 3.- S. 175-186.

15. келі й печери в історії т культурі ст род внього н селення кр їни: н ук. конф., ьвів, 2-3 лютого 1995 р. / нститут укр їнозн вств ім. . рип'якевич кр їни. ьвівський музей історії релігії. рхеологічн комісія у ьвові. - ьвів, 1995. - 128 с. 
16. DemetrykiewiczW. Groty wykute w skałah Galicyi Wshodnej pod względem archeologicznym / W. Demetrykiewicz. - Kraków, 1903. - 26 s.

17. ищук . ерківн зустріл скелел зів [ лектронний ресурс]. - ежим доступу: http://www.report.if.ua/sport/sport/tserkivna-zustrila-skelelaziv.

18. рушевський . сторія кр їни- уси. .2. к льні городки і печери [ лектронний pecypc]. - ежим доступу: http://litopys.org.ua/hrushrus/iur29901.htm.

m ття: н дійшл до ред кції 03.09.2013

доопр изов н 30.09 .2013

прийнят до друку 10.10.2013

\title{
GEOMORPHOLOGIC PECULIARITIES OF THE TSERKOVYANS'KIY ROCK COMPLEX IN SKOLIVSKI BESKYDY
}

\author{
Marta Zozulia \\ Ivan Franko National University of Lviv, \\ P. Doroshenko Str., 41, UA - 79000 Lviv, Ukraine
}

Geomorphologic peculiarities of location, morphometrical parameters and agents of formation of the tors in the village of Tserkivna in Eastern Beskydy are described. Previous studies of rocks in the area are analyzed. Measurements are done and Rose diagram of the direction of strike of cracks of different origins in the body of sandstone is built. A biodiversity on the rocks, characteristics and causes of localization of different plant species on them are described. Recommendations to promote the popularization of rocks in Tserkivna, informing about their geomorphologic, historical and geographical features, value and uniqueness among tourists and scientists are designed. Additional measures to preserve these objects are also recommended.

Key words: morphometry of the tors, forms of rocks, fissures, forming of the crags.

\section{рт озуля}

ьвовский н иион льный университет имени в н ул. . орошенко, 41, 79000, ьвов, кр ин

пис но геоморфологические условия р змещения, приведено морфометрические п р метры и ф кторы формиров ния комплекс песч никовых ск л в с. ерковн в восточной ч сти ескидов.

ро н лизиров но предв рительные исследов ния ск л в этом р йоне. дел ны измерения и построено розу-ди гр мму н пр вления простир ния трещин р зного генезис в теле песч ников. $\quad$ тко опис но биор знообр зие ск л, особенности и причины лок лиз ции р зличных видов р стений н них. формулиров но рекоменд ции, призв ны способствов ть популяриз ции ск л в ерковне, информиров нию об их геоморфологических и историко-геогр фических особенностях, ценности и уник льности среди туристов и ученых. кже рекомендуются дополнительные меры для сохр нения этих объектов.

лючевые слов : морфометрия ск л, формы ск л, трещины, формиров ние ск л. 